УДК 342.7:351.74

DOI https://doi.org/10.32837/yuv.v0i1.1570

\author{
В. Бондар, \\ кандидат юридичних наук, доцент, \\ завідувач кафедри адміністративного права та адміністративного процесу \\ Херсонського факультету \\ Одеського державного університету внутрішніх справ
}

\title{
ШЛЯХИ ПРОТИДІї ДОМАШНЬОМУ НАСИЛЬСТВУ В УКРАЇНІ
}

Ухвалення у 2018 році нового Закону України «Про запобігання та протидію домашньому насильству» $€$ вагомою зміною в кращий бік, але, щоб він працював на повну, треба докласти багато зусиль усього населення країни. I це так, адже все населення країни, від малого до старшого, має працювати в потрібному напрямі, щоб ця проблема не була такою нагальною та глобальною.

Давайте розглянемо визначення, що ж таке безпосередньо домашнє насильство. Закон нам дає таке визначення: домашне насильство - діяння (дії або бездіяльність) фізичного, сексуального, психологічного чи економічного насильства, що здійснюються в сім'ї, або в межах місця проживання, або між родичами, або між колишнім або нинішнім подружжям, або між іншими особами, які спільно проживають (проживали) однією сім'єю, але не перебувають (не перебували) в родинних стосунках або в шлюбі між собою, незалежно від того проживає (проживала) особа, яка вчинила домашнє насильство, у тому ж місці, що й постраждала від неї особа, а також загрози скоєння таких діянь.

Проблема домашнього насильства $€$ ще загальнодержавною, тому що ми повинні виховати дітей, які не боятимуться своїх батьків, своїх рідних. Якщо до них не будуть застосовані жоден із видів домашнього насильства, то й вони в подальшому не будуть цього робити щодо батьків і своїх дітей.

У Законі сказано, що в разі, якщо постраждалою особою є дитина, будь- які дії, що здійснюються стосовно неї, базуються на принципах, визначених Конвенцією ООН про права дитини, Конвенцією Ради Європи про захист дітей від сексуальної експлуатації та сексуального насильства, Європейською конвенцією про здійснення прав дітей і законодавчими актами України у сфері захисту прав дитини $[1 ; 2 ; 3$; $4 ; 5 ; 6]$.

Захист дітей від домашнього насильства в сім'ї має бути першочерговим завданням у превентивної діяльності органів національної поліції України, адже державна політика у сфері запобігання та протидії домашньому насильству спрямована на забезпечення комплексного інтегрованого підходу до подолання домашнього насильства, надання всебічної допомоги постраждалим особам і затвердження ненасильницького характеру приватних відносин.

Основними напрямами реалізації державної політики у сфері запобігання та протидії домашньому насильству є:

1) запобігання домашньому насильству;

2) ефективне реагування на факти домашнього насильства шляхом уведення механізму взаємодії суб'єктів, які здійснюють заходи у сфері запобігання та протидії домашньому насильству;

3) надання допомоги й захисту постраждалим особам, забезпечення відшкодування шкоди, заподіяної домашнім насильством;

4) належне розслідування фактів домашнього насильства, залучення 
кривдників до передбаченої законом відповідальності й зміна їхньої поведінки.

Згідно з п. 2 ст. 6 цього Закону [6], спеціально уповноваженими органами у сфері запобігання та протидії домашньому насильству є:

1) центральний орган виконавчої влади, що забезпечує формування державної політики у сфері запобігання та протидії домашньому насильству;

2) центральний орган виконавчої влади, що реалізує державну політику у сфері запобігання та протидії домашньому насильству;

3) Рада Міністрів Автономної Республіки Крим, місцеві державні адміністрації, у тому числі їх структурні підрозділи, до повноважень яких належить здійснення заходів у сфері запобігання та протидії домашньому насильству;

4) сільські, селищні, міські, районні в містах (у разі їх створення) ради, їх виконавчі органи, до повноважень яких належить здійснення заходів у сфері запобігання та протидії домашньому насильству.

Також, відповідно до п. 3 ст. 6 Закону [6], до інших органів та установ, на які покладаються функції щодо здійснення заходів у сфері запобігання та протидії домашньому насильству, належать:

1) служби у справах дітей;

2) уповноважені підрозділи органів Національної поліції України;

3) органи управління освітою, навчальні заклади, установи й організації системи освіти;

4) органи охорони здоров'я, установи й заклади охорони здоров'я;

5) центри 3 надання безоплатної вторинної правової допомоги;

6) суди;

7) прокуратура;

8) уповноважені органи з питань пробаціі.

До повноважень центрального органу виконавчої влади, що забезпечує формування державної політики у сфері запобігання та протидії домашньому насильству, належать:
1) формування державної політики у сфері запобігання та протидії домашньому насильству;

2) нормативно-правове регулювання в сфері запобігання та протидіі домашньому насильству;

3) координація діяльності суб'єктів, що здійснюють заходи у сфері запобігання та протидії домашньому насильству;

4) забезпечення розроблення та затвердження типових програм для постраждалих, а також методичних рекомендацій щодо їх виконання;

5) забезпечення розроблення та затвердження типових програм для кривдників, а також методичних рекомендацій щодо ï виконання в тому числі з урахуванням віку, стану здоров'я, статі кривдника;

6) здійснення методичного забезпечення місцевих державних адміністрацій та органів місцевого самоврядування в сфері запобігання та протидії домашньому насильству;

7) затвердження стандартів надання соціальних послуг потерпілим особам і методики визначення потреб територіальних громад у створенні спеціалізованих служб підтримки постраждалих;

8) здійснення міжнародного співробітництва у сфері запобігання та протидії домашньому насильству.

Згідно зі ст. 10 Закону [6], до повноважень уповноважених підрозділів органів Національної поліції України у сфері запобігання та протидії домашньому насильству належать:

1) виявлення фактів домашнього насильства і своєчасне реагування на них; результатів оцінювання ризиків у порядку, визначеному центральним органом виконавчої влади, що забезпечує формування державної політики у сфері запобігання та протидії домашньому насильству, спільно з Національною поліцією України;

2) прийом i розгляд заяв i повідомлень про скоєння домашнього насильства, у тому числі розгляд тих заяв, надійшли в колцентр 3 питань запобігання та протидії домашньому насильству, насильства за озна- 


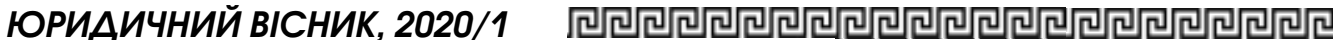

кою статі й насильства щодо дітей, ужиття заходів для його припинення та надання допомоги постраждалим особам з урахуванням результатів оцінювання ризиків у порядку, визначеному центральним органом виконавчої влади, що забезпечує формування державної політики у сфері запобігання та протидії домашньому насильству, разом із Національною поліцією України;

3) інформування потерпілих про їхні права, заходи й соціальні послуги, якими вони можуть скористатися;

4) винесення термінових заборонних приписів щодо кривдників;

5) постановка на профілактичний облік кривдників і проведення 3 ними профілактичної роботи в порядку, визначеному законодавством;

6) здійснення контролю за виконанням кривдниками спеціальних заходів протидії домашньому насильству протягом терміну їх дії;

7) анулювання дозволів на право придбання, зберігання, носіння зброї ii власникам у разі вчинення ними домашнього насильства, а також вилучення зброї та боєприпасів у порядку, визначеному законодавством;

8) взаємодія 3 іншими суб'єктами, що здійснюють заходи у сфері запобігання та протидії домашньому насильству;

9) звітність центральному органу виконавчої влади, що реалізує державну політику у сфері запобігання та протидії домашньому насильству, про результати здійснення повноважень у цій сфері в порядку, визначеному центральним органом виконавчої влади, що забезпечує формування державної політики у сфері запобігання та протидії домашньому насильству.

Також уповноважені підрозділи органів Національної поліції України здійснюють повноваження у сфері запобігання та протидії домашньому насильству 3 урахуванням міжнародних стандартів реагування правоохоронних органів на випадки домашнього насильства й оцінювання ризиків.
Поліцейські можуть проникати в житло особи без умотивованого рішення суду в невідкладних випадках, пов'язаних із припиненням учиненого акту домашнього насильства, у разі безпосередньої небезпеки для життя або здоров'я потерпілого особи.

Органи національної поліції Украіни повинні не тільки виявляти та притягати винних за вчинення домашнього насильства, а й проводити цілеспрямовані превентивні заходи щодо запобігання фактам домашнього насильства.

Під час здійснення превентивних заходів поліцейські мають виконувати такі завдання:

1) визначення стану, причин і передумов поширення домашнього насильства;

2) підвищення рівня обізнаності населення про форми, прояви, причини й наслідки домашнього насильства;

3) сприяння розумінню суспільством природи домашнього насильства, його непропорційного впливу на жінок і чоловіків, у тому числі осіб з інвалідністю, вагітних жінок, дітей, недієздатних осіб, осіб похилого віку;

4) формування в суспільстві нетерпимого ставлення до насильницьких моделей поведінки, небайдужого ставлення до постраждалих, насамперед постраждалих дітей, усвідомлення домашнього насильства як порушення прав людини;

5) викорінення дискримінаційних уявлень про соціальні ролі й обов'язки жінок і чоловіків, а також будь-яких звичаїв і традицій, що на них грунтуються;

6) заохочення всіх членів суспільства, передусім чоловіків і хлопців, активно сприяти запобіганню домашнього насильства.

У ході виявлення фактів домашнього насильства до кривдників застосовуються спеціальні заходи з протидіï домашньому насильству, до яких належать:

1) строковий заборонний припис щодо кривдника;

2) обмежувальний припис щодо кривдника; 
3) постановка на профілактичний облік кривдника та проведення 3 ним профілактичної роботи;

4) направлення кривдника на проходження програми для кривдників.

Також постраждала особа може вимагати від кривдника компенсації іï витрат на лікування, отримання консультацій або на оренду житла, яке вона знімає (знімала) 3 метою запобігання вчиненню стосовно неї домашнього насильства, а також періодичних витрат на іï утримання, утримання дітей або інших членів сім’ї, які перебувають (перебували) на утриманні кривдника, у порядку, передбаченому законодавством [6].

У разі порушення кримінального провадження у зв'язку 3 учиненням домашнього насильства перелік заходів щодо тимчасового обмеження прав або покладання обов'язків на особу, яка підозрюється, обвинувачується в учиненні кримінального правопорушення, пов'язаного 3 домашнім насильством, або визнана винною в його вчиненні, а також порядок застосування таких заходів визначаються Кримінальним кодексом України та Кримінальним процесуальним кодексом України.

3 метою запобігання повторному вчиненню домашнього насильства й забезпечення виконання програми для кривдника дитина кривдника може бути тимчасово влаштована до родичів, у сім'ю патронатного вихователя або в установу для дітей незалежно від форми власності й підпорядкування, у яких створені належні умови для проживання, виховання, навчання і реабілітації дитини відповідно до ії потреб.

У зв'язку з новітніми змінами законодавства України та адаптацією вітчизняного законодавства до законодавства Європейського Союзу не можна говорити, що ця проблема замовчується, але вона не вирішена повністю.

Хоча основну роботу в цьому напрямі покладено на Національну поліцію Україні, не можна говорити, що вона буде вирішена повністю тільки правоохоронними органами, адже, щоб своєчасно реагувати на факти скоєння домашнього насильства, органи національної поліції самі не повинні відчувати кадровий голод, тому що саме кадровий голод і $€$ основною причиною проведення превентивних заходів у цьому напрямі в невідповідному обсязі та невідповідної якості.

Проблема домашнього насильства не нова, вона існувала ще з початку зародження людства, з початку зародження громад $i$ понять сімейних звичаїв. Aле те, що сьогодні деякі країни навчилися адекватно боротися із иією проблемою, а деякі поки просто мовчать про нё̈, не означає, що проблеми не існуе взагалі. Ухвалення у 2018 році нового Закону України «Про запобігання та протидію домашньому насильству» $\epsilon$ вагомою зміною в кращий бік, але, щзоб він працював на повну, треба докласти багато зусиль усього населення країни. I иее так, адже все населення краіни, від малого до старшого, має працуювати в потрібному напрямі, щоб ия проблема не була такою нагальною й глобальною. Згідно $з$ новим Законом, «домашнім насильством» уважаються всі акти фізичного, сексуального, психологічного або економічного насильства, учинені між колишнім чи теперішнім подружжям або людьми, які разом живуть чи жили. Закон передбачає, що стороні, яка скоїла насильство, буде заборонено телефонувати та листуватися з потерпілим, наближатися до нього на певну відстань. Якщо раніше домашнім насильством уважалися інциденти в подружжі, mо тепер розширюеться коло осіб. До нього тепер зараховують колишнього чоловіка/дружину, громадянські илюби (спільне пронивання без реєстраиіі). Розширено коло осіб, яких визнають кривдниками: прийомні батьки, особи, які спільно проживають чи проживали в одній родині, рідні брати, сестри, опікуни 
й інщі родичі - дядько, тітка, племінниці, двоюрідні брати, сестри, двоюрідні дідусі ma бабусі.

Ключові слова: адміністративна діяльність, органи національної поліції, протидія домашньому насильству.

\section{Bondar V. Ways against domestic violence in Ukraine}

The problem of domestic violence is not new, it has existed since the beginning of humanity, from the beginning of the emergence of communities and concepts of family customs. But the fact that today some countries have learned to adequately deal with this problem, and some are still silent about it, does not mean that the problem does not exist at all. The passage of a new law on preventing and combating domestic violence in 2018 is a significant change for the better, but in order for it to work in full, much effort must be made by the entire population of the country. And this is so, because the whole population of the country from small to older must work in the right direction so that this problem is not so urgent and global. According to the new Law, "Domestic Violence" means all acts of physical, sexual, psychological or economic violence committed between a former or current spouse or people who live or have lived together. The law stipulates that the perpetrator will be prohibited from calling and corresponding with the victim or approaching him for a certain distance. If incidents of marriage were previously considered domestic violence, now the circle of people is expanding. If incidents of marriage were previously considered domestic violence, now the circle of people is expanding. It now includes ex-spouses, civil marriages (cohabitation without registration). Extended range of persons recognized as perpetrators: foster parents, persons living or living together in the same family, siblings, guardians and other relatives - uncle, aunt, nieces, cousins, sisters, grandparents.

Key words: administrative activity, national police bodies, counteracting domestic violence.

\section{Література}

1. Конституиія України. URL: https: / zakon.rada (дата звернення: 25.04.2020).

2. Про Національну поліиії: Закон України. URL: http://zakon.rada.gov.ua (дата звернення: 28.04.2020).

3. Кодекс України про адміністративні правопорушення. URL: http: / / zakon.rada. gоv.иа (дата звернення: 28.04.2020).

4. Про основи соціальної захищеності осіб з інвалідністю в Україні : Закон України. URL: http://zakon.rada.gov.ua (dama звернення: 27.04.2020).

5. Декларація про поліцію : Резолюиія Парламентської Асамблеї Ради Европи № 690 (1979 p.). URL: https: / / zakon.rada. gov.ua/laws/show/994_803 (Jama звернення: 29.04.2020).

6. Про запобігання та протидію домашньому насильству : Закон України. URL: https: //zakon.rada.gov.ua (dama звернення: 25.04.2020). 